\title{
SKIRTINGŲ KINEZITERAPIJOS METODIKŲ POVEIKIS ASMENŲ, TURINČIŲ SMILKININIO APATINIO ŽANDIKAULIO SĄNARIO FUNKCINIŲ SUTRIKIMŲ IR APATINİ KRYŽMINİ SINDROMĄ, SKAUSMUI IR FUNKCINEI BŪKLEI
}

\author{
Karolina Plaušinytė, Pavelas Zachovajevas \\ Lietuvos sporto universitetas
}

\section{SANTRAUKA}

Tyrimo pagrindimas. Dauguma kineziterapeutų, ị kuriuos kreipiasi ligoniai, kol kas nèra susipažinę su smilkininio apatinio žandikaulio sąnario (SAŽS) funkciniais sutrikimais, netaisyklingo sąkandžio ir kūno laikysenos pokyčiais bei tarpusavio ryšio problema. Netaisyklinga laikysena turi įtakos asmenims, besiskundžiantiems juosmeninès stuburo dalies (JSD) skausmu, o dantų sąkandžio ir kūno laikysenos tarpusavio ryšys - tai pagrindas diskusijai apie diagnostikos ir gydymo įtraukimą, ịvertinus asmenų, turinčių netaisyklingą sąkandị ir SAŽS funkcinių sutrikimų, kūno laikysenos pokyčius (Rodriguez-Blanco et al., 2015).

Tikslas - nustatyti skirtingų kineziterapijos metodikų poveikį asmenų, turinčių smilkininio apatinio žandikaulio sąnario funkcinių sutrikimų ir apatinį kryžminį sindromą, skausmui ir funkcinei būklei.

Metodai. Pirmai tiriamųų grupei taikyti kvėpavimo, stabilizavimo, motorinès kontrolès ir tempimo pratimai, antrai - kvejpavimo, stabilizavimo, motorinės kontrolès ir tempimo pratimai kartu taikant SAŽS mobilizaciją ir kramtomųų raumenų atpalaidavimo techniką. İvertinta SAŽS funkcija ir sąkandis, JSD funkcija ir dubens padètis, prieš taikytas skirtingas kineziterapijos metodikas ir po jų.

Rezultatai. Keturias savaites taikyta tik skirtingo pobūdžio pratimų programa vertintų rodiklių tendencingiems pokyčiams įtakos neturèjo, statistinis reikšmingumas nenustatytas $(p>0,05)$. Grupèje, kuriai buvo taikomi skirtingo pobūdžio pratimai kartu taikant SAŽS mobilizaciją ir kramtomujų raumenų atpalaidavimo techniką, buvo pastebèta rodiklių pokyčių tendencija, tačiau statistinis reikšmingumas nenustatytas $(p>0,05)$.

Išvados. SAŽS funkcija ir sąkandis, taip pat JSD funkcija, dubens padètis po skirtingų kineziterapijos metodikų taikymo statistiškai reikšmingai nepakito.

Raktažodžiai: smilkininis apatinis žandikaulio sąnarys, funkciniai sutrikimai, apatinis kryžminis sindromas, kineziterapija.

\section{IVADAS}

Smilkininio apatinio žandikaulio sąnario sutrikimai - tai reikšminga visuomenès sveikatos problema. Dantų sąkandžio ir kūno laikysenos tarpusavio ryšys yra pagrindas diskusijai apie diagnostikos ir gydymo ịtraukimą, įvertinus asmenų, turinčių netaisyklingą sąkandị ir smilkininio apatinio žandikaulio sąnario funkci-

Copyright (C) 2020 Karolina Plaušinytė, Pavelas Zachovajevas. Published by Lithuanian Sports University.

This is an Open Access article distributed under the terms of the Creative Commons Attribution 4.0 International License, which permits unrestricted use, distribution, and reproduction in any medium, provided the original author and source are credited. 
nių sutrikimų, kūno laikysenos pokyčius (Rodriquez-Blanco et al., 2015). Deja, dauguma kineziterapeutu, ị kuriuos kreipiasi ligoniai, kol kas nèra susipažinę su smilkininio apatinio žandikaulio sąnario funkciniais sutrikimais, netaisyklingo sąkandžio ir kūno laikysenos, kuri sukelia lètini juosmeninès stuburo dalies skausmą ir leidžia nustatyti apatini kryžminị sindromą, pokyčiais bei tarpusavio ryšio problema, o mokslinė literatūra dažniausiai paneigia arba patvirtina tik labai silpną tarpusavio sąsają.

SAŽS sutrikimai opi ir klinikinè problema (Liu, Steinkeler, 2013). K. C. Lee su bendraautoriais (2020) teigia, kad SAŽS sutrikimai dažnai egzistuoja kartu su kitais sisteminiais sutrikimais, tokiais kaip fibromialgija, apatinès nugaros dalies skausmas, krūtininès stuburo dalies skausmas, lètinis nuovargio sindromas, dirgliosios žarnos sindromas, îtampos tipo ir migreniniai galvos skausmai bei alerginės būklès. Autoriai teigia, kad SAŽS sutrikimų atsiradimas kartu su apatinès stuburo dalies skausmu stipriai paveikia žmogaus gyvenimą. Svarbi ankstyva ligonių, besiskundžiančių apatinès nugaros dalies skausmu, SAŽS sutrikimų diagnostika norint išvengti didesnių funkcinių apribojimų.

Tyrimo tikslas - nustatyti skirtingų kineziterapijos metodikų poveikị asmenų, turinčių smilkininio apatinio žandikaulio sąnario funkcinių sutrikimų ir apatinị kryžminį sindromą, skausmui ir funkcinei būklei.

\section{METODAI}

Tyrimas kiekybinis, organizuotas remiantis Helsinkio deklaracijos etikos principais. 2019 m. lapkričio 15 d. gautas Lietuvos sporto universiteto Bioetikos komisijos leidimas NR. MNL - KIN(M)-2019-219 atlikti tyrimą.

\section{Tiriamųjų atrankos kriterijai}

Itraukimo kriterijai: maudimas, skausmas vienoje iš burnos kramtomųų raumenų pusių, amžius - 20-40 m., ịprotis sukąsti dantis, kandžioti lūpas, griežimas dantimis, nuovargis, stresas, galvos skausmas, netaisyklinga laikysena, juosmeninès stuburo dalies lètinis nespecifinis skausmas, trunkantis ilgiau nei 3 mènesius ir atsiradęs be tam tikros priežasties.

Neįtraukimo kriterijai: migrena, galvos kraujagyslių ligos, neseniai atliktos dantų procedūros, sergantys sisteminėmis, reumatinėmis, degeneracinėmis ligomis, sergantys cukriniu diabetu, tureję žandikaulio lūžių, patiriantys tremorą, vartojantys analgetikus ar priešuždegiminius vaistus, turintys žalingų ịpročių, jaučiantys kaklinès stuburo dalies ar pečiu lanko skausmą, jaučiantys ūmų iki 1 mėnesio trukmès smilkininio apatinio žandikaulio ar juosmeninès stuburo dalies skausmą, pasižymintį specifine kilme, kuriai būdingos patirtos ịvairios traumos, lūžiai, disko 
išvaržos, aukštas fizinio aktyvumo lygis, kuris turètų ịtakos rankų ir kojų raumenų aktyvumui, hipertonusui ir skausmui.

Tyrimo organizavimas. Buvo tiriama 30 20-40 metų amžiaus vyrų ir moterų. Tiriamieji suskirstyti ị dvi grupes po 15 žmonių. Pirmai grupei buvo taikytas konservatyvus gydymas, skirtingo pobūdžio pratimų programa, antrai - konservatyvus gydymas, skirtingo pobūdžio pratimų programa bei SAŽS mobilizacija ir kramtomujų raumenų atpalaidavimo technika. Norint gauti kuo homogeniškesnes grupes, tikslesnius rezultatus, tiriamieji turejo atitikti numatytus kriterijus.

Tyrimas truko 4 savaites. Pratimų programą sudare 10-15 pratimų. Pratimams atlikti buvo naudojamos papildomos priemonès, tokios kaip įvairių dydžių kamuoliukai ir kamuoliai, įvairios nestabilios plokštumos, gumos.

Smilkininio apatinio žandikaulio mobilizacija ir kramtomujų raumenų atpalaidavimas buvo atliekamas rankomis, naudojant sterilias pirštines. SAŽS mobilizacijos technikos trukmè - $90 \mathrm{~s}$ kiekvienai padèčiai ir pusei. Kramtomujų raumenų atpalaidavimo technika apėmè 5-6 cm miofascijinę liniją nuo kramtomujų raumenų prisitvirtinimo vietos pradžios iki pabaigos, kiekvienoje zonoje išlaikant spaudimą iki 4-6s ir kartojant 3 kartus.

Procedūros ir užsièmimai vyko 5 kartus per savaitę. Tiriamujų grupei, kuriai buvo taikomos SAŽS mobilizacijos ir kramtomujų raumenų technikos kartu su kvėpavimo, stabilizavimo, motorinès kontrolès ir tempimo pratimais, užsièmimų trukmè svyravo apie $1 \mathrm{~h}$ ir 30 min, o likusiai grupei, kuriai taikème tik kvėpavimo, stabilizavimo, motorinès kontrolès ir tempimo pratimus, apie $1 \mathrm{~h}$.

Tyrimą sudarè pirminis ištyrimas (funkcinès būklès ir skausmo intensyvumo vertinimas), gydymas (1 grupe - konservatyvus gydymas, skirtingo pobūdžio pratimų programa; 2 grupè - konservatyvus gydymas, skirtingo pobūdžio pratimų programa, smilkininio apatinio žandikaulio mobilizacija ir kramtomujų raumenų atpalaidavimo technika), galutinis ištyrimas (funkcinès būklès ir skausmo intensyvumo vertinimas).

\section{Tyrimo instrumentai}

Vizualusis sąkandžio vertinimas. Sąkandị vertinome pagal Angle sąkandžio vertinimo klasifikaciją. Angle sistema apibūdinama kaip paprastai naudojama ir neužimanti daug laiko.

Tiriamojo buvo prašoma atsisèsti ant kẻdès be atlošo, pẻdas pilnai pastatyti ant žemès, suglausti, rankas nuleisti prie šonų. I burną buvo ịdedamas specialus plètiklis tam, kad būtų galima ịvertinti tiriamiojo sąkandị. Užtikrinant burnos plètiklio sterilumą, prieš kiekvieną naudojimą ir po jo, pletiklis dezinfekuojamas. Viso ištyrimo metu buvo naudojamos vienkartinès medicininès pirštinès (Miguel-Neto et al., 2010). 
İstačius burnos plètiklį, tiriamajam leidžiama apsiprasti, jei reikia, plètiklio padètis koreaguojama tam, kad tiriamasis jaustų kuo mažiau diskomforto. Vèliau tiriamojo prašoma sukąsti dantis, vertinama sagitalinė viršutinių ir apatinių pirmujų krūminių dantų bei ilčių okliuzija.

Aktyviu juosmenines stuburo dalies judesiu vertinimas. Aktyvūs JSD judesiai buvo vertinami centimetrine juostele. Vertinome krūtininės-juosmeninės stuburo dalies lenkimą, tiesimą, lenkimus ị dešinę ir ị kairę. Matuojant tiriamojo prašoma stovèti tiesiai, pėdas pilnai pastatyti ant žemès, rankas nuleisti prie šonų. Centimetrinès juostelès pradžia dedama ties C7 keterine atauga, rodiklis matuojamas iki S1 keterinès ataugos, užrašomas. Vèliau tiriamojo prašoma pasilenkti pirmyn tiek, kiek išeina ir kol nejaučiamas diskomfortas arba skausmas. Tokiu pat principu dar kartą matuojamas rodiklis ir užrašomas gautas skirtumas (Magee, 2008).

Vertinant tiesimo judesį, matavimo eiga išlieka tokia pati, tik tiriamojo prašoma tiestis atgal tiek, kol nejaučiamas diskomfortas arba skausmas (Magee, 2008).

Matuojant lenkimus ị dešinę ir ị kairę, tiriamojo pradinẻ padètis išlieka ta pati, matuojamas atstumas nuo rankų pirštų galiukų iki žemės, tuomet prašoma tiek, kiek išeina, pasilenkti ị šoną, ir rodiklis matuojamas dar kartą užrašant skirtumą (Magee, 2008).

Aktyvūs smilkininio apatinio žandikaulio judesiu vertinimas. Aktyvūs SAŽS judesiai buvo vertinami goniometrijos metodu. Tiriamojo buvo prašoma atsisėsti ant kèdès be atlošo, pẻdas pilnai pastatyti ant žemès, suglausti, rankas nuleisti prie šonų. Buvo prašoma atlikti vertinamus apatinio žandikaulio judesius kuo didesne amplitude, išvengiant kompensacinių judesių. Vertinome išsižiojimą, apatinio žandikaulio šoninị nuokrypị ir išstūmimą pirmyn. Apatinio žandikaulio judesiai vertinami frontalioje plokštumoje, tiriamajam sèdint veidu i tyreją (Gallo et al., 2017).

Dubens padeties vertinimas. AND linkio sagitalioje plokštumoje nuokrypiai vertinti pagal W. W. K. Hoeger'io (1987) laikysenos vertinimo skalę. Tiriamojo buvo prašoma atsistoti tiesiai, pédas pilnai pastatyti ant žemès, suglausti, rankas nuleisti prie šonų. Dubens padètis ịvertinama balais ( 5 balai - gerai, 3 - patenkinamai, 1 - blogai) (Hoeger, W. W. K., Hoeger, S. A., 2010).

Matematinė statistika. Tyrimo duomenys buvo apskaičiuoti naudojant kompiuterinę SPSS 21 ir Excel 2013 programas. Duomenys nurodomi pateikiant vidurkius ir standartinius nuokrypius. Požymių paplitimas lyties ir grupès aspektu išreiškiamas procentais. Statistinis patikimumas buvo vertinamas Wilcoxon'o testu. Jei $\mathrm{p}<0,05$, skirtumas patikimas ir rezultatas yra statistiškai reikšmingas, jei $\mathrm{p}>0,05$ - skirtumas nepatikimas, rezultatas statistiškai nereikšmingas (Pukènas, 2004). 


\section{TYRIMO REZULTATAI}

Lyginant JSD amplitudes I grupejje, lenkimo amplitudè tendencingai padidejo $3,4 \mathrm{~cm}$ (prieš intervenciją $-11,7 \pm 7,3 \mathrm{~cm}$, po $-15,07 \pm 6,4 \mathrm{~cm}$ ). Tiesimosi atgal amplitudè pakito $2,2 \mathrm{~cm}$ (prieš intervenciją $-6,1 \pm 3,12 \mathrm{~cm}$, po $-8,3 \pm 3,4 \mathrm{~cm}$ ). Šoninio lenkimosi ị dešinę amplitude padidejo 1,6 cm (prieš intervenciją $-12 \pm$ $2,7 \mathrm{~cm}$, po $-13,6 \pm 3,9 \mathrm{~cm}$ ), šoninio lenkimosi ị kairę $-1 \mathrm{~cm}$ (prieš intervenciją $13 \pm 3,9 \mathrm{~cm}$, po $-14 \pm 3,8 \mathrm{~cm})$. Statistinis reikšmingumas nenustatytas $(\mathrm{p}>0,05)$ (1 pav.).

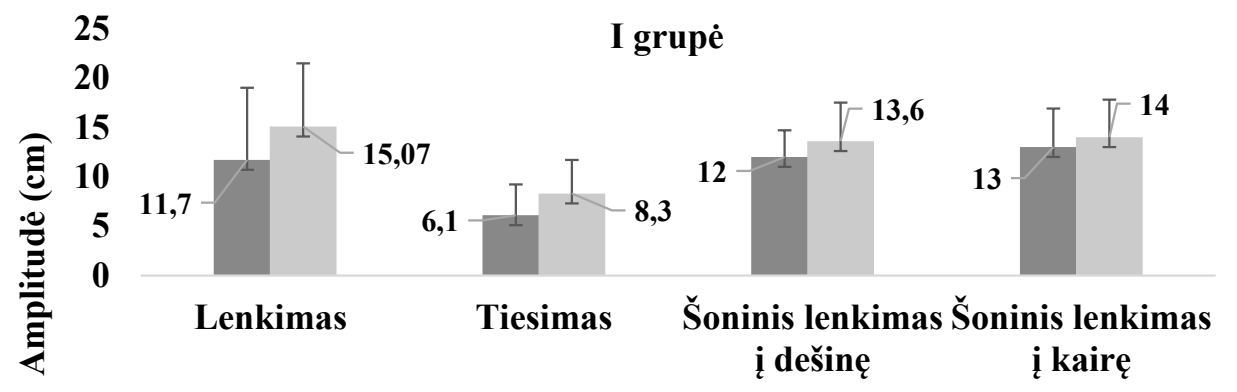

\section{Prieš $\square$ Po}

1 pav. JSD aktyvių judesių amplitudžių vertinimas goniometrijos metodu. Skirtingo pobūdžio pratimų grupè

Lyginant JSD lenkimo amplitudes II grupeje, lenkimo amplitudè tendencingai padidèjo $5,3 \mathrm{~cm}$ (prieš intervenciją $-10,7 \pm 7,2 \mathrm{~cm}$, po $-16 \pm 6,4 \mathrm{~cm}$ ), tiesimosi atgal - pakito 4,2 cm (prieš intervenciją $-5,1 \pm 3,02 \mathrm{~cm}$, po $-9,3 \pm 3,4 \mathrm{~cm}$ ). Šoninio lenkimosi ị dešinę padidèjo $3,6 \mathrm{~cm}$ (prieš intervenciją $-11 \pm 2,7 \mathrm{~cm}$, po $-14,6 \pm$ $3,9 \mathrm{~cm}$ ), o šoninio lenkimosi ị kairę padidèjo $3 \mathrm{~cm}$ (prieš intervenciją $-12 \pm 3,9 \mathrm{~cm}$, po $-15 \pm 3,8 \mathrm{~cm})$. Statistinis reikšmingumas nenustatytas $(\mathrm{p}>0,05)(2 \mathrm{pav}$.$) .$ 


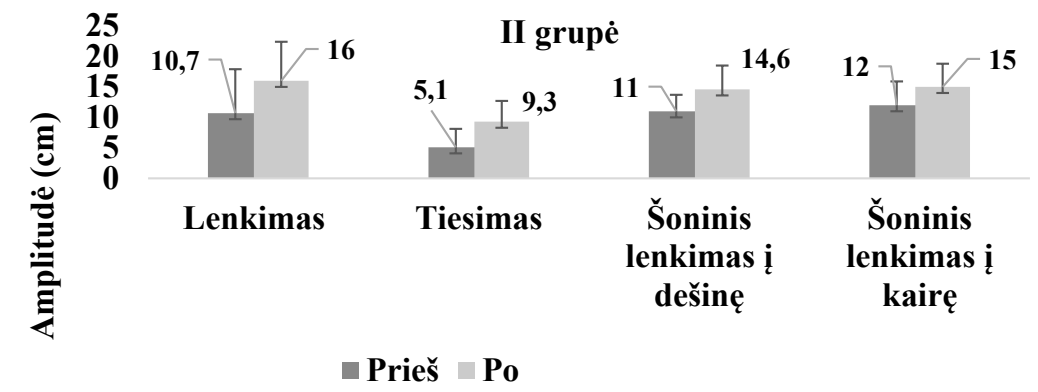

2 pav. JSD aktyvių judesių amplitudžių vertinimas goniometrijos metodu

\section{Skirtingo pobūdžio pratimụ, SAŽS mobilizacijos ir kramtomụjų raumenụ atpalaidavimo technikos grupè}

Lyginant I ir II grupes tarpusavyje, tendencija turèjo polinkį didèti labiau II grupejje, statistinis reikšmingumas nebuvo nustatytas $(\mathrm{p}>0,05)$.

Lyginant SAŽS judesių amplitudes I grupeje, išsižiojimo amplitudè tendencingai padidejo $2 \mathrm{~mm}$ (prieš intervenciją $-42,7 \pm 4,9 \mathrm{~mm}$, po $-44,6 \pm 3,5 \mathrm{~mm}$ ). Nuokrypio ị dešinę amplitudè padidejo $0,5 \mathrm{~mm}$ (prieš intervenciją $-11,5 \pm 0,9 \mathrm{~mm}$, po $-12 \pm 1,3 \mathrm{~mm}$ ). Nuokrypio i kairę amplitudè padidèjo $0,8 \mathrm{~mm}$ (prieš intervenciją $-11,3 \pm 0,9 \mathrm{~mm}$, po $-12,1 \pm 0,9 \mathrm{~mm}$ ). Išstūmimo ị prieki amplitudè padidejjo $0,2 \mathrm{~mm}$ (prieš intervenciją $-5,6 \pm 1,9 \mathrm{~mm}$, po $-5,8 \pm 1,01 \mathrm{~mm}$ ). Statistinis reikšmingumas nenustatytas ( $\mathrm{p}>0,05)$ ( 3 pav.).

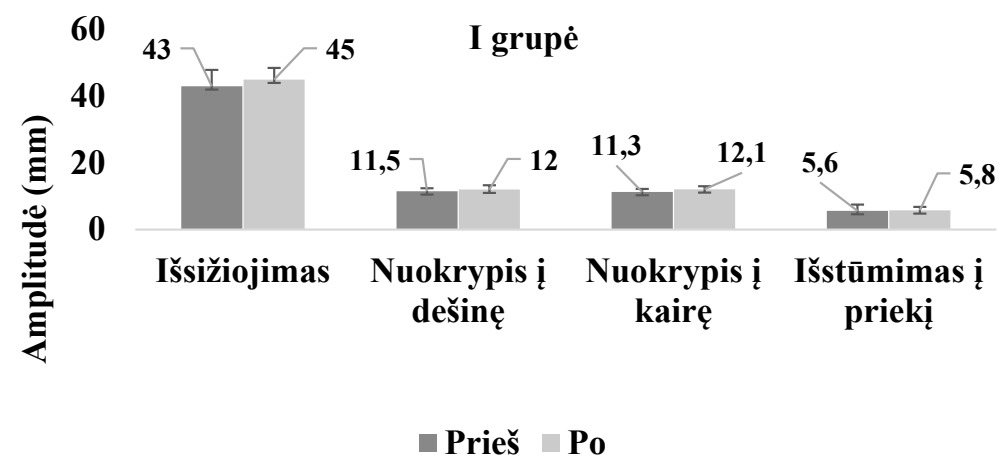

3 pav. SAŽS aktyvių judesių amplitudžių vertinimas goniometrijos metodu 


\section{Skirtingo pobūdžio pratimų grupè}

Lyginant SAŽS judesių amplitudes II grupèje, išsižiojimo amplitudè tendencingai padidèjo $3,4 \mathrm{~mm}$ (prieš intervenciją $-42,7 \pm 4,9 \mathrm{~mm}$, po $-46,1 \pm 3,2 \mathrm{~mm}$ ). Nuokrypio ì dešinę amplitudè padidèjo 1,6 mm (prieš intervenciją $-11,7 \pm$ $1,2 \mathrm{~mm}$, po $-13,3 \pm 1,3 \mathrm{~mm}$ ). Nuokrypio ị kairę amplitudè padidèjo $1,4 \mathrm{~mm}$ (prieš intervenciją $-12 \pm 1,3 \mathrm{~mm}$, po $-13,4 \pm 1,4 \mathrm{~mm}$ ). Išstūmimo ị priekị amplitudè sumažějo $0,1 \mathrm{~mm}$ (prieš intervenciją $-6,1 \pm 1,4 \mathrm{~mm}$, po $-6 \pm 1,1 \mathrm{~mm}$ ). Statistinis reikšmingumas nenustatytas $(\mathrm{p}>0,05)(4$ pav.).

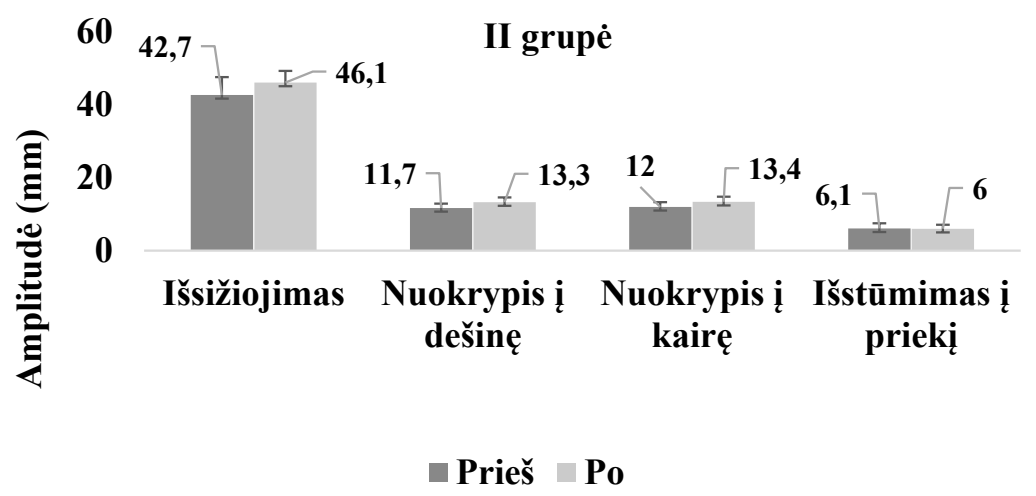

4 pav. SAŽS aktyvių judesių amplitudžių vertinimas goniometrijos metodu

\section{Skirtingo pobūdžio pratimų, SAŽS mobilizacijos ir kramtomųjų raumenų atpalaidavimo technikos grupé}

Lyginant I ir II grupes tarpusavyje, rodikliai skyrèsi mažai, statistinis reikšmingumas nenustatytas $(\mathrm{p}>0,05)$.

Dubens padeties rodiklis buvo vertinamas pasitelkus W. W. K. Hoeger'io (1987) laikysenos skalę. I grupèje, kuriai buvo taikomi tik skirtingo pobūdžio pratimai, statistinis reikšmingumas prieš intervenciją ir po jos nenustatytas ( $p>0,05)$.

II grupeje, kurioje buvo taikoma skirtingo pobūdžio pratimų programa, SAŽS mobilizacija ir kramtomujų raumenų atpalaidavimas, statistinis reikšmingumas prieš intervenciją ir po jos nenustatytas $(p>0,05)$. Prieš taikytą intervenciją ir po jos rodikliai tarp grupių nesiskyré, statistinis reikšmingumas nenustatytas ( $p>$ $0,05)$.

Sąkandžio klasė buvo vertinama pagal Angle klasifikaciją. I grupèje, kuriai buvo taikomi tik skirtingo pobūdžio pratimai, statistinis reikšmingumas prieš intervenciją ir po jos nenustatytas $(p>0,05)$. Vyraujanti sąkandžio klasė antra. 
II grupeje, kurioje buvo taikoma skirtingo pobūdžio pratimų programa, SAŽS mobilizacija ir kramtomujų raumenų atpalaidavimas, statistinis reikšmingumas prieš intervenciją ir po jos nenustatytas $(p>0,05)$. Vyraujanti sąkandžio klasė pirma.

\section{REZULTATŲ APTARIMAS}

Atliekant ši tyrimą buvo siekiama nustatyti skirtingų kineziterapijos metodiku poveikị asmenų, turinčių SAŽS funkcinių sutrikimų ir apatinị kryžminị sindromą, skausmui ir funkcinei būklei (AKS). Remiantis moksline literatūra ir holistiniu požiūriu apie fascijinio ryšio teoriją tarp SAŽS ir kitų kūno dalių teigiama, kad sutrikus judesiui vienoje kūno dalyje gali atsirasti disfunkcija ir distalinėse dalyse (Saito et al., 2009; Rodriguez-Blanco et al., 2015).

K. C. Lee su bendraautoriais (2020) nustatè statistiškai reikšmingus rodikliu skirtumus, susiedami apatinès nugaros dalies (AND) skausmus, kitus raumenų ir griaučių skausmus, SAŽS skausmą. Autoriai teigia, kad SAŽS sutrikimų atsiradimas kartu su AND skausmu stipriai paveikia žmogaus tolesni gyvenimą. Svarbi ligonių, patiriančių AND skausmus, ankstyva SAŽS sutrikimų diagnostika norint išvengti didesnių funkcinių apribojimų.

Atlikdami tyrimą nustatėme, kad pagerèjo ir JSD bei SAŽS aktyvių judesių amplitudès. Statistiškai reikšmingų skirtumų neaptikta, tačiau abiejose grupèse rodikliai turèjo tendenciją gerèti. Lyginant I ir II grupes tarpusavyje, tendencija turẻjo polinkị didèti labiau toje grupejje, kuriai taikème ne tik skirtingo pobūdžio pratimus, bet ir SAŽS mobilizaciją kartu su kramtomujų raumenų atpalaidavimo technika. Pavyzdžiui, mūsų laikysena kinta pagal tai, kiek arti ar toli SAŽS yra nuo kintančios dalies ar dalių, sudarančių visumą (Marchena-Rodriquez et al., 2018). Atsižvelgiant ị tai, kad griaučių ir raumenų sistemą sudaro kelios raumenų grandinès, kurios trapusavyje susijusios viena su kita, bet koks vieno segmento sutrikimas sukels persitvarkymą visame kūne (Saito et al., 2009).

E. Bair'as su bendraautoriais (2016) teigia, kad viena iš priežaščių, rodančių silpnas tarpusavio sąsajas, yra per daug toli viena nuo kitos esančios kūno dalys. W. C. Munhoz'o ir W. T. Hsing'o (2014), C. Rodriguez-Blanco'o su bendraautoriais (2015) tyrimai rodo, kad norint atpalaiduoti minkštuosius audinius raumenys gali būti tempiami gretimose ir (arba) distalinèse strūktūrose, kurios gali būti susijusios pagal miofascijinę grandinę, perduodančią signalus ị tikslią sriti. Visgi vertètų pasirinkti ilgesnę intervencijų trukmę bei papildomai įvertinti bendrą laikyseną, kaklo ir pečių lanko tonusą. Tai leistų sudaryti platesnę pratimų programą, teigiamai keistų tyrimo rezultatus. Mūsų tyrimo metu SAŽS funkcija ir sąkandis, 
taip pat juosmeninès stuburo dalies funkcija ir dubens padètis po taikytų skirtingu kineziterapijos metodikų taikymo pakito statistiškai nereikšmingai.

\section{IŠVADOS}

Smilkininio apatinio žandikaulio sąnario funkcija ir sąkandis, taip pat juosmeninès stuburo dalies funkcija ir dubens padètis po skirtingų kineziterapijos metodikų taikymo pakito statistiškai nereikšmingai.

\section{Finansavimas: nèra. \\ Interesų atskleidimas: nèra.}

\section{LITERATŪRA}

Bair, E., Gaynord, S., Sladea, G. D. et al. (2016). Identification of clusters of individuals relevant to temporomandibular disorders and other chronic pain conditions. Health and Human Services Public Access, 157 (6), 1266-1278.

Gallo, L. M., Frankhauser, N., Gonzalez, Y. M. et al. (2017). Jaw closing movement and sex differences in temporomandibular joint energy densities. Journal of Oral Rehabilitation, 45, 97-103.

Hoeger, W. W. K., Hoeger, S. A. (2010). Principles and labs for fitness \& wellness. 10th edition. Wadsworth (USA): Cengage Learning.

Hoeger, W. W. K., Hoeger, S. A. (2010). Principles and Labs for Fitness \& Welness. $10^{\text {th }}$ Edition. Wadsworth (USA): Cengage Learning.

Lee, K. C., Wu, Y. T., Chien, W. C. et al. (2020). The prevalence of first-onset temporomandibular disorder in low back pain and associated risk factors A nationwide population-based cohort study with a 15-year follow-up. Medicine, 99 (3), 1-8.

Liu, F., Steinkeler, A. (2013). Epidemiology, diagnosis, and treatment of temporomandibular disorders. Dental Clinics of North America, 57 (3), 465-479.

Magee, D. J. (2008). Orthopedic physical assessment. Elsevier Health Sciences. $6^{\text {th }}$ Edition. P 1-1184.

Miguel-Neto, A. B., Nishio, C., Mucha, C. N. (2010). Agreement evaluation of a newly proposed system for Malocclusion Classification. International Journal of Odontostomatology, 4 (1), 33-41.

Munhoz, W. C., Hsing, W. T. (2014). Interrelations between orthostatic postural deviations and subjects' age, sex, malocclusion, and specific signs and symptoms of functional pathologies of the temporomandibular system: A preliminary correlation and regression study. Cranio: the Journal of Craniomandibular Practice, 32 (3), 175-186.

Pukènas, K. (2004). Sportinių tyrimy duomeny analizé SPSS programa. Kaunas: Lietuvos kūno kultūros akademija.

Rodriguez-Blanco, C., Cocera-Morata, F. M., Heredia-Rizo, A. M. et al. (2015). Immediate effects of combining local techniques in the craniomandibular area and hamstring muscle stretching in subjects with temporomandibular disorders: A randomized controlled study. The Journal of Alternative and Complementary Medicine, 21 (8), 1-9.

Saito, E. T., Akashi, P. M. H., Sacco, I. C. N. (2009). Global body posture evaluation in patients with temporomandibular joint disorder. Clinical Science, 64 (1), 35-39. 


\title{
EFFECTS OF DIFFERENT PHYSICAL THERAPY METHODS ON PAIN AND FUNCTIONAL STATUS IN PERSONS WITH THE TMJ FUNCTIONAL DISORDERS AND LOWER CROSS SYNDROME
}

\author{
Karolina Plaušinytė, Pavelas Zachovajevas \\ Lithuanian Sports University
}

\begin{abstract}
Background. Most physiotherapists are not involved in this problem and correlations are very weak. Therefore, it is considered that in the presence of an irregular dental clench of the subjects, limited movements of the TMJ, lower cross syndrome should also be detected and different physiotherapy methodologies will be found to be positive indicators alteration of functional disorders of the TMJ and lower cross syndrome. The formation of irregular posture affects people who complain of low back pain. Relationship between dental clench and posture is a basis for discussion on the inclusion of diagnosis and treatment in the assessment of postural changes in individuals with irregular clench and dysfunction of the TMJ.

Aim. The purpose was to determine the effect of different physiotherapy methodologies on pain and functional status in persons with dysfunction of the TMJ and lower cross syndrome.
\end{abstract}

Methods. Only breathing, stabilization, motor control and stretching exercises are applied to group I. Breathing, stabilization, motor control and stretching exercises together with TMJ mobilization and chewing muscle recognition technique are applied to group II. We evaluated the active function of the TMJ and dental clench as well as the lumbar spine and pelvic position before and after different physical therapy methods.

Results. Only the exercise program of different types applied for four weeks did not affect the tendency changes in the evaluated indicators, the statistical significance was not determined $(p>0.05)$. For the group treated with different types of exercises in combination with TMJ mobilization and chewing muscle relaxation technique, a tendency in the change of indicators was observed, but the statistical significance was not determined $(\mathrm{p}>0.05)$.

Conclusion. The function of the TMJ and dental clench, the function of the lumbar spine and pelvic position after different physical therapy methods statistical significance did not change.

Keywords: TMJ, functional disorders, lower cross syndrome, physical therapy.

Gautas 20200701

Priimtas 20200929 